\title{
Prevalence and Impact of Depression, Anxiety and Stress on CD4+ Cell Counts of HIV/AIDS Patients Receiving HAART in Ghana
}

\section{Alexander Kwakye*}

Department of Molecular Medicine, Kwame Nkrumah University of Science and Technology (KNUST), Ghana

\begin{abstract}
Psychosocial disorders such as depression, anxiety and stress are more prevalent among HIV/AIDS patients compared to the general population. These psychosocial disorders impact negatively on HIV AIDS patients on highly active anti-retroviral therapy (HAART). This study determined how these psychosocial disorders impact CD4+ cell counts of HIVIAIDS patients receiving HAART in a peri-urban hospital in Kumasi, Ghana. This cross-sectional study included randomly selected 138 HIVIAIDS patients receiving HAART. DASS-21 questionnaire was used to determine the depression, anxiety and stress levels of participants. Venous blood sample was collected from each participant for the estimation of CD4+ cell counts. The mean age of the study sample was $45.2 \pm 10$ years, with about $79 \%$ of them being females. The prevalence of depression, anxiety and stress among the participants were $87 \%, 78.3 \%, 71 \%$ respectively. The median (Inter-quartile range, IQR) CD4+ count of participants with depression compared to nondepressed [340.8 $(261,713)$ cells/ $\mu \mathrm{L}$ vs. $418(242,481.2)$ cells/ $\mu \mathrm{L} ; \mathrm{p} \leq 0.0001]$, anxiety compared to non-anxious [318 $(124,540) \mu \mathrm{L}$ vs. $438(267,487) \mu \mathrm{L} ; \mathrm{p} \leq 0.0001]$ and stress disorders compared to non-stressed $[370(251,467) \mu \mathrm{L} v s$. $484(424.5,752.3) \mu \mathrm{L} ; \mathrm{p} \leq 0.0001]$ were significantly lower. Depression and anxiety correlated negatively with CD4+ cell count of participants [Depression; $(r=-0.13, p=0.556)$, Stress; $(r=-0.2, p=0.359)$ ]. This study shows that depression, anxiety and stress have negative impact on CD4+ cell counts of HIVIAIDS patients receiving HAART.
\end{abstract}

Keywords: HIV/AIDs; Psychosocial disorders; CD4+ cell counts; HAART

\section{Introduction}

HIV/AIDS continues to be a major cause of death worldwide despite various interventions to reduce its incidence and prevalence, and possibly eradicate it totally [1]. According to the UNAIDS Gap Report, there was an estimated 35 million people living with HIV/ AIDS worldwide in 2014 [2]. Certain studies have reported that HIV/AIDS patients have a two-fold increased risk of developing psychosocial disorders such as depression, anxiety and stress [3], which have been found to have adverse effects on HIV/AIDS progression [4]. The causes of these psychosocial disorders in people living with HIV/AIDS are many. One documented cause is stigmatization [5]. In developing countries like Ghana, HIV/AIDS related stigmatization and discrimination are very high [6] which could result in the high incidence of psychosocial disorders among HIV/AIDS patients in such regions [7]. Another possible cause is the presence of viral reservoirs in the central nervous system [8] which lead to neurocognitive disorders in living with HIV/AIDS [9]. Neurological impairment is associated with psychosocial disorders like depressive syndrome among people living with HIV/AIDS [10].

Highly Active Anti-Retroviral Therapy (HAART), combinations of anti-retroviral drugs are the recommended treatment of all HIV patients by the World Health Organization (WHO). It is estimated that as at mid-2016, 18.2 million people living with HIV/AIDS were receiving HAART [11]. Since its inception in the late 1990s, HAART has positively influenced the life expectancy of people living with HIV/ AIDS $[12,13]$. The efficacy of HAART has been found to be affected by certain factors. One of these factors is the presence of viral reservoirs such as in the central nervous system (CNS) [14]. The virus in these reservoirs are altered and different from those in blood, making HAART less effective on viruses in these reservoirs [8]. Another cause is psychosocial disorders such as depression, anxiety and stress. These psychosocial disorders have been found to cause medication non- adherence in HIV/AIDS patients [15] which affects the efficacy of medications.

Despite the association of psychosocial disorders and the efficacy of HAART, the impact of psychosocial disorders on HIV/AIDS treatment has not been adequately studied. Particularly, there have not been enough studies to determine how psychosocial disorders affect CD4+ cell counts which are widely used as the gold standard in most facilities to monitor treatment of HIV/AIDS [16].

In this study, we determined the prevalence of depression, anxiety and stress as well as their impact on the CD4+ cell counts among HIV/ AIDS patients receiving HAART.

\section{Methodology}

\section{Study design and study site}

This cross-sectional study was conducted from November 2015 to June 2016 at Aninwah Medical Center. The hospital is located at Emena, a peri-urban town in the Ashanti Region of Ghana. The hospital serves an estimated 600 patients living with HIV/AIDS. Trading is the commonest occupation among the inhabitants.

*Corresponding author: Alexander Kwakye, Department of Molecular Medicine Kwame Nkrumah University of Science and Technology (KNUST), Ghana, Tel: 233266045858; E-mail: kwakyealex900@yahoo.com

Received July 24, 2018; Accepted November 30, 2018; Published December 07, 2018

Citation: Kwakye A (2018) Prevalence and Impact of Depression, Anxiety and Stress on CD4+ Cell Counts of HIVIAIDS Patients Receiving HAART in Ghana. J AIDS Clin Res 9: 781. doi: 10.4172/2155-6113.1000781

Copyright: (C) 2018 Kwakye A. This is an open-access article distributed under the terms of the Creative Commons Attribution License, which permits unrestricted use, distribution, and reproduction in any medium, provided the original author and source are credited. 


\section{Study population and selection}

HIV/AIDS patients who have been on HAART for more than 6 months and agreed to participate in the study were recruited. 138 participants were recruited into the study.

\section{Socio-demographics and psychosocial disorders}

A well-structured questionnaire was used to collect information on socio-demographic characteristics of participants who agreed to be recruited into the study. Depression, anxiety and stress levels were measured with DASS-21 questionnaire.

\section{CD4+ Cell counts estimation}

Venous blood (3 mls) was taken from each participant for estimation of $\mathrm{CD} 4+\mathrm{T}$ lymphocyte cell counts. This was determined using the Becton Dickinson FAS Count system (Becton, Dickinson and Company, California, USA). The BD FAS Count system uses flow cytometry for the quantification of the CD4 T Lymphocytes.

\section{Data analysis}

Continuous variables were expressed as mean \pm Standard deviation (SD) and median (inter-quartile range) where appropriate. Categorical variables were expressed as frequency (n) and percentages (\%). Associations between variables were done using Mann-Whitney nonparametric t-test or Fisher exact tests where appropriate. p-value less

\begin{tabular}{|c|c|c|}
\hline Variables & Frequency (138) & Percentages (\%) \\
\hline \multicolumn{3}{|c|}{ Age } \\
\hline$<40$ & 30 & 21.7 \\
\hline $40-50$ & 72 & 52.2 \\
\hline$>50$ & 36 & 26.1 \\
\hline Mean age \pm SD & $45.2 \pm 10.0$ & -- \\
\hline \multicolumn{3}{|c|}{ Gender } \\
\hline Female & 110 & 79.7 \\
\hline Male & 28 & 20.3 \\
\hline \multicolumn{3}{|c|}{ Marital Status } \\
\hline Single & 22 & 15.9 \\
\hline Married & 54 & 39.1 \\
\hline Divorced & 18 & 13.0 \\
\hline Widowed & 38 & 27.5 \\
\hline Co-habiting & 6 & 4.4 \\
\hline \multicolumn{3}{|c|}{ Level of Education } \\
\hline No formal education & 24 & 18.8 \\
\hline Primary & 84 & 65.6 \\
\hline Secondary & 14 & 10.9 \\
\hline Tertiary & 6 & 4.7 \\
\hline \multicolumn{3}{|c|}{ Residency } \\
\hline Owned & 26 & 21.0 \\
\hline Rented & 54 & 43.6 \\
\hline Family House & 44 & 35.5 \\
\hline \multicolumn{3}{|c|}{ CD4+ cell count (cells/ml) } \\
\hline Less than 200 & 22 & 15.9 \\
\hline $200-499$ & 82 & 59.4 \\
\hline$>500$ & 34 & 24.6 \\
\hline Average CD4+ $\pm \mathrm{SD}$ & $428.4 \pm 263.4$ & \\
\hline \multicolumn{3}{|c|}{ Hemoglobin conc. (g/dl) } \\
\hline Less than 10 & 20 & 14.5 \\
\hline $10.0-12.5$ & 72 & 52.2 \\
\hline Greater than 12.5 & 44 & 31.9 \\
\hline
\end{tabular}

Table 1: Socio-demographic characteristics of participants. than 0.05 were considered statistically significant for all analysis using GraphPad Prism 6 and IBM Statistical Package for the Social Sciences (SPSS) version 20.00 (SPSS Inc, Chicago, USA).

\section{Ethical consideration}

Ethical clearance for commencement of the study was sought from the Committee on Human Research, Publication and Ethics (CHRPE), Kwame Nkrumah University of Science and Technology, School of Medical Sciences (KNUST-SMS). Informed consent.

\section{Results}

The prevalence of depression was $87.0 \%$. Anxiety and stress had prevalence of $78.3 \%$ and $71.0 \%$ respectively among our study population.

Table 1 shows the socio-demographic characteristics of the participants. The mean age was $(45.2 \pm 10.0)$ years with majority $(52.2 \%)$ being in the age group (40-50) years and least $(21.7 \%)$ in $<40$ years. Females accounted for $79.7 \%$ whereas males formed $20.3 \%$. More than one-third (39.1\%) were married whereas $15.9 \%$ and $13.0 \%$ were single and divorced respectively. The average CD4+ cell count of the participants was $428.4 \pm 263.4$.

Table 2 shows the relationship of the various socio-demographic characteristics of participants and depression. Majority of the depressed participants were females 96 (80.0\%), and most of the participants who were married $8(44.4 \%)$ were not depressed. There was significant association between depression and CD $4+$ cell counts $(p \leq 0.0001)$. The

\begin{tabular}{|c|c|c|c|}
\hline Variable & $\begin{array}{c}\text { Depressed } \\
\mathrm{N}=120(87 \%)\end{array}$ & $\begin{array}{c}\text { Non depressed } \\
N=36(13 \%)\end{array}$ & $p$-value \\
\hline \multicolumn{4}{|c|}{ Gender } \\
\hline Male & $24(20.0)$ & $4(22.2)$ & \multirow[t]{2}{*}{0.877} \\
\hline Female & $96(80.0)$ & $14(77.8)$ & \\
\hline \multicolumn{4}{|c|}{ Marital Status } \\
\hline Single & $20(16.7)$ & $2(11.1)$ & \multirow[t]{5}{*}{0.558} \\
\hline Married & $46(38.3)$ & $8(44.4)$ & \\
\hline Divorced & $14(11.7)$ & $4(22.2)$ & \\
\hline Widowed & $36(30.0)$ & $2(11.1)$ & \\
\hline Co-habiting & $4(3.3)$ & $2(11.1)$ & \\
\hline \multicolumn{4}{|c|}{ Level of Education } \\
\hline No formal education & $18(15.0)$ & $6(33.3)$ & \multirow[t]{4}{*}{0.606} \\
\hline Primary & $74(61.7)$ & $10(55.6)$ & \\
\hline Secondary & $12(10.0)$ & $2(11.1)$ & \\
\hline Tertiary & $6(5.0)$ & $0(0.0)$ & \\
\hline \multicolumn{4}{|c|}{ Duration of HAART } \\
\hline Less than 3 years & $16(13.3)$ & $2(11.1)$ & \multirow[t]{3}{*}{0.8668} \\
\hline $3-6$ years & $74(61.7)$ & $10(55.6)$ & \\
\hline More than 6 years & $30(25.0)$ & $6(33.3)$ & \\
\hline \multicolumn{4}{|c|}{ CD4 (cells/ml) } \\
\hline Less than 200 & $20(16.7)$ & $2(11.1)$ & \multirow[t]{3}{*}{0.1000} \\
\hline $200-499$ & $72(60.0)$ & $10(55.6)$ & \\
\hline $401-800$ & $54(23.3)$ & $6(33.3)$ & \\
\hline $\begin{array}{l}\text { Median (Inter- } \\
\text { quartile range) }\end{array}$ & $340.8(261,713)$ & $418(242,481.2)$ & $<0.0001$ \\
\hline \multicolumn{4}{|c|}{$\mathrm{HB}(\mathrm{g} / \mathrm{dl})$} \\
\hline Less than 10 & $18(15.0)$ & $2(11.1)$ & \multirow[t]{3}{*}{0.948} \\
\hline $10-12.5$ & $62(51.7)$ & $10(55.6)$ & \\
\hline More than 12.5 & $38(31.7)$ & $6(33.3)$ & \\
\hline
\end{tabular}

Table 2: Comparison of socio-demographic distribution of participants and depression. 
Page 3 of 5

median CD4+ cell count of the depressed participants was 340.8 (261, $713)$ and that for those not depressed was $418(481.2,242)$. Very few participants who were depressed had been on HAART for less than 3 years $16(13.3 \%)$.

Table 3 shows the relationship of the various socio-demographic characteristics of participants and anxiety. Most females 90 (83.3\%) experienced anxiety disorders. Among the participants who were divorced, 18 (16.4\%) expressed anxiety disorders. The median CD4+ cell count of those who suffered anxiety and those who were nonanxious were $318(124,540)$ and $438(267,487)$ respectively. About a quarter of those who were anxious 28 (25.9\%) had been on HAART for more than 6 years.

Table 4 shows the relationship of the various socio-demographic characteristics of participants and stress. More than $80 \%$ of the participants who were stressed were females 80 (81.6\%). The average CD4+ cell count of those who were stressed was $426.5 \pm 261.3$, and those who were not stressed was $432.8 \pm 275.5$.

Majority of those who were stressed had been on HAART between 3 to 6 years $60(61.2 \%)$. Only $8(8.2 \%)$ of the stressed participants had $\mathrm{CD} 4+$ cell counts greater than 800 cells $/ \mathrm{ml}$.

The Figures below show the correlation of depression, anxiety and stress and CD4+ cell counts of the participants. Increasing levels of depression, stress but not anxiety result in slight decrease in CD4+ cell counts, $\mathrm{r}=-0.13,0.1$ and -0.2 respectively for depression, anxiety and stress.

\begin{tabular}{|c|c|c|c|}
\hline Variable & $\begin{array}{c}\text { Anxious } \\
\mathrm{N}=108(78.3 \%)\end{array}$ & $\begin{array}{l}\text { Non anxious } \\
\mathrm{N}=30(21.7 \%)\end{array}$ & p-value \\
\hline \multicolumn{4}{|c|}{ Gender } \\
\hline Male & $18(16.7)$ & $10(33.3)$ & \multirow[t]{2}{*}{0.156} \\
\hline Female & $90(83.3)$ & $20(66.7)$ & \\
\hline \multicolumn{4}{|c|}{ Marital Status } \\
\hline Single & $16(14.5)$ & $6(21.4)$ & \multirow[t]{5}{*}{0.447} \\
\hline Married & $20(36.4)$ & $14(50)$ & \\
\hline Divorced & $18(16.4)$ & $0(0.0)$ & \\
\hline Widowed & $32(29.1)$ & $6(21.4)$ & \\
\hline Co-habiting & $4(3.0)$ & $2(7.1)$ & \\
\hline \multicolumn{4}{|c|}{ Level of Education } \\
\hline $\begin{array}{l}\text { No formal } \\
\text { education }\end{array}$ & $14(13.0)$ & $10(41.7)$ & \multirow[t]{4}{*}{0.062} \\
\hline Primary & $76(70.4)$ & $8(33.3)$ & \\
\hline Secondary & $12(11.1)$ & $4(16.7)$ & \\
\hline Tertiary & $6(5.5)$ & $2(8.3)$ & \\
\hline \multicolumn{4}{|c|}{ Duration of HAART } \\
\hline Less than 3 years & $14(13.0)$ & $8(26.7)$ & \multirow[t]{3}{*}{0.434} \\
\hline $3-6$ years & $66(61.1)$ & $16(53.3)$ & \\
\hline More than 6 years & $28(25.9)$ & $6(20.0)$ & \\
\hline \multicolumn{4}{|c|}{ CD4+ cell count } \\
\hline Less than 200 & $14(12.9)$ & $8(26.7)$ & \multirow[t]{3}{*}{0.200} \\
\hline $200-499$ & $68(63.0)$ & $14(46.6)$ & \\
\hline$>500$ & $26(12.1)$ & $8(26.7)$ & \\
\hline $\begin{array}{l}\text { Median (Inter- } \\
\text { quartile range) }\end{array}$ & $318(124,540)$ & $438(267,487)$ & $<0.0001$ \\
\hline \multicolumn{4}{|c|}{ Hemoglobin level } \\
\hline Less than 10 & $14(13.0)$ & $6(20.0)$ & \multirow[t]{3}{*}{0.483} \\
\hline $10-12.5$ & $54(50.0)$ & $18(60.0)$ & \\
\hline More than 12.5 & $38(35.2)$ & $6(20.0)$ & \\
\hline
\end{tabular}

Table 3: Comparison of socio-demographic distribution of participants and anxiety disorders.

\begin{tabular}{|c|c|c|c|}
\hline Variable & $\begin{array}{c}\text { Stressed } \\
N=98(71 \%)\end{array}$ & $\begin{array}{c}\text { Non stressed } \\
\mathrm{N}=40(29 \%)\end{array}$ & $\mathrm{p}$-value \\
\hline \multicolumn{4}{|c|}{ Gender } \\
\hline Male & $18(18.4)$ & $10(25.0)$ & \multirow[t]{2}{*}{0.534} \\
\hline Female & $80(81.6)$ & $30(75.0)$ & \\
\hline \multicolumn{4}{|c|}{ Marital Status } \\
\hline Single & $14(14.3)$ & $8(20.0)$ & \multirow[t]{5}{*}{0.912} \\
\hline Married & $38(38.8)$ & $16(40.0)$ & \\
\hline Divorced & $12(12.2)$ & $6(15.0)$ & \\
\hline Widowed & $30(30.6)$ & $8(20.0)$ & \\
\hline Co-habiting & $4(4.1)$ & $2(5.0)$ & \\
\hline \multicolumn{4}{|c|}{ Level of Education } \\
\hline No formal education & $12(12.2)$ & $12(30)$ & \multirow[t]{4}{*}{0.322} \\
\hline Primary & $60(61.9)$ & $24(60)$ & \\
\hline Secondary & $10(10.2)$ & $4(10)$ & \\
\hline Tertiary & $6(6.1)$ & $0(0)$ & \\
\hline \multicolumn{4}{|c|}{ Duration of HAART } \\
\hline Less than 3 years & $12(12.2)$ & $10(25.0)$ & \multirow[t]{3}{*}{0.225} \\
\hline $3-6$ years & $60(61.2)$ & $22(55.0)$ & \\
\hline More than 6 years & $26(26.6)$ & $14(35.0)$ & \\
\hline \multicolumn{4}{|c|}{ CD4+ cell count (cells/ml) } \\
\hline Less than 200 & $14(14.3)$ & $6(15.0)$ & \multirow[t]{3}{*}{0.4000} \\
\hline $200-499$ & $62(63.3)$ & $20(50.0)$ & \\
\hline$>500$ & $11(22.4)$ & $16(40.0)$ & \\
\hline $\begin{array}{l}\text { Median (Inter- } \\
\text { quartile range) }\end{array}$ & $370(251,467)$ & $484(424.5,752.3)$ & $<0.0001$ \\
\hline \multicolumn{4}{|c|}{ Hemoglobin level } \\
\hline Less than 10 & $16(16.3)$ & $4(10.0)$ & \multirow[t]{3}{*}{0.190} \\
\hline $10-12.5$ & $44(44.9)$ & $28(70.0)$ & \\
\hline More than 12.5 & $36(36.7)$ & $8(20.0)$ & \\
\hline
\end{tabular}

Table 4: Comparison of socio-demographic distribution of participants and stress.

\section{Discussion}

This study measured depression, anxiety and stress among HIV/ AIDS patients receiving HAART and their impact on the CD4+ cell counts of participants.

About $87.0 \%, 78.3 \%$ and $71 \%$ prevalence of depression, anxiety and stress respectively among the participants (Figure 1). These proportions are similar to those observed by a cross-sectional study conducted among HIV/AIDS patients living in Ghana [17]. These proportions are also close to another cross-sectional study conducted among people living with HIV/AIDS in Malaysia [18]. The slight differences could have resulted from differences in demographics and cultural values in the studied participants.

The median CD4+ cell count of patients who were depressed was lower than those who were not depressed (Table 2). There was a negative correlation between depression and the CD4+ cell counts of the participants (Figure 2). Kaharuza et al., found in their crosssectional study among HIV/AIDS living in Uganda that depression was associated with low levels of CD4+ cell counts [19]. In a longitudinal study in the United States, Ickovics et al., found that CD4+ cell counts were negatively affected by psychosocial disorders such as depression [20].

Those who had anxiety disorders had lower median CD4+ cell count than those who were not anxious (Table 3). However, unlike the other psychosocial disorders, we found that anxiety disorders do not affect CD4+ cell counts negatively (Figure 2). A similar observation was made by Fincham et al., who found that anxiety had no effect on CD4+ cell counts in their study in South Africa [21]. 


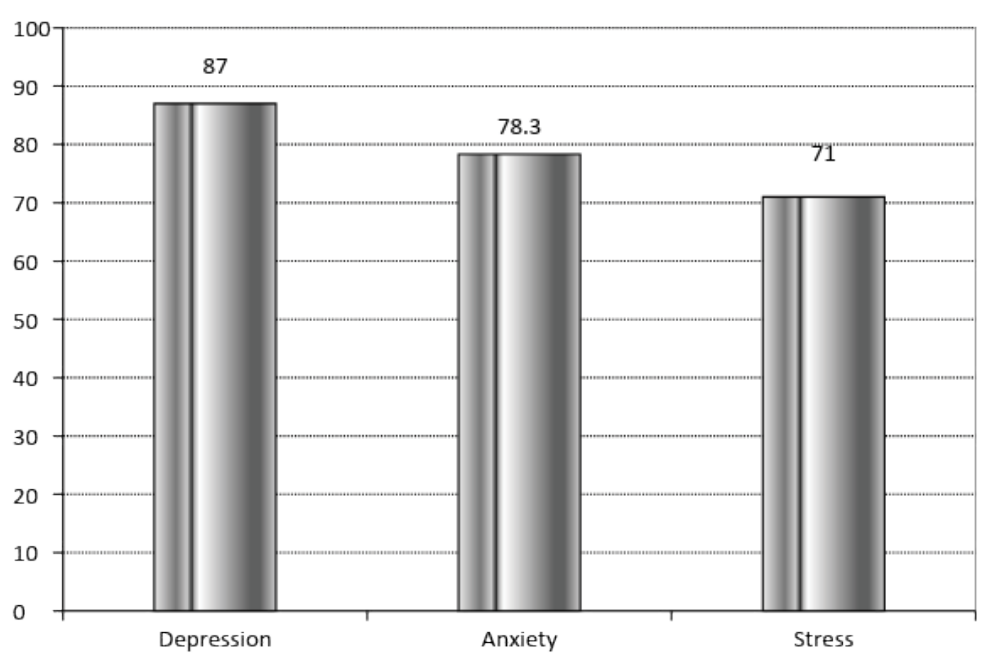

Figure 1: Prevalence of depression, anxiety and stress among study participants.
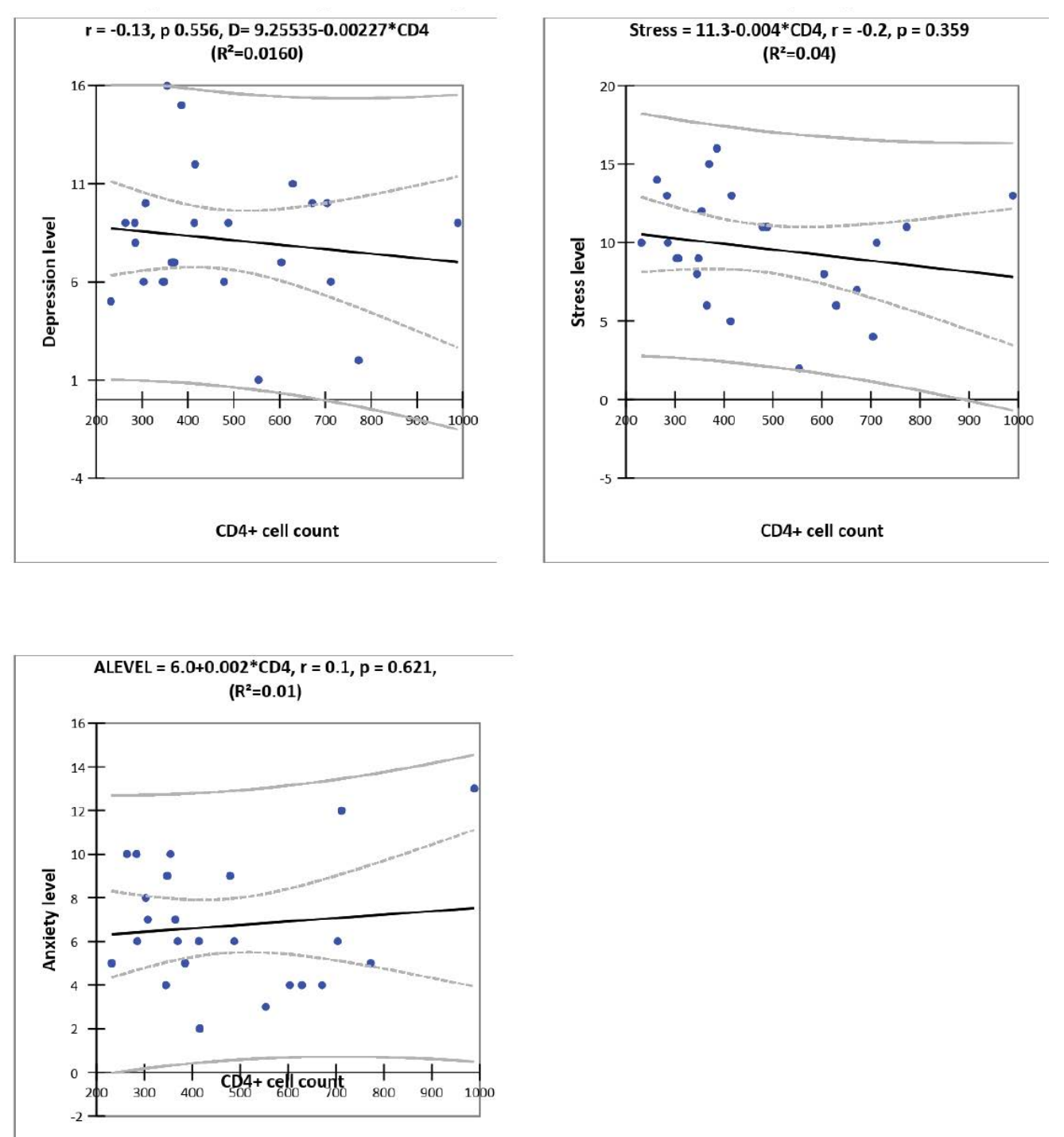

Figure 2: Effect of depression, anxiety and stress on the CD4+ cell count of participants. 
Citation: Kwakye A (2018) Prevalence and Impact of Depression, Anxiety and Stress on CD4+ Cell Counts of HIV/AIDS Patients Receiving HAART in Ghana. J AIDS Clin Res 9: 781. doi: 10.4172/2155-6113.1000781

The participants who were stressed had lower CD4+ cell counts than those who were not stressed (Table 4). Stress had a negative correlation with CD4+ cell counts (Figure 2). Jane Lesserman and colleagues had found in their cross-sectional study in North Carolina, USA that stressful life events had significant increase HIV disease progression [22]. Our study shows that this progression may be due to the negative impact of stress on CD4+ cell counts.

The negative impact of psychosocial disorders on CD4+ cell counts of the participants could be attributed to several factors. In particular, it is possible that medication non-adherence observed among depressed, anxious or stressed HIV/AIDS patients $[15,23,24]$ could have resulted in the decrease in CD4+ cell counts observed in the participants in this study. Considering the gravity of the positive influence that HAART has had on CD4+ cell counts [12], it is very likely that non-adherence to HAART should have led to decreased CD4+ cell counts as observed in our study.

One limitation of our study is the use of questionnaire- based assessment in measuring the psychosocial disorders instead of diagnostic interviews.

Further studies need to be done using diagnostic interviews to assess the depression, anxiety and stress. In addition, future studies should focus on the impact of antidepressants on HIV/AIDS management.

\section{Conclusion}

Depression, anxiety and stress are prevalent among HIV/AIDS patients and they have been found to have negative impact on CD4+ cell counts. To effectively treat HIV/AIDS patients, it is necessary to examine the presence of such disorders in HIV/AIDS patients and treat them accordingly. Policies regarding the management of HIV/ AIDS should be revised to possibly include antidepressants in the drugs administered to HIV/AIDS patients as well as diagnosing and treating other psychosocial disorders alike.

\section{References}

1. http://www.unaids.org/sites/default/files/media_asset/UNAIDS_FactSheet en.pdf.

2. http://www.unaids.org/en/media/unaids/contentassets/documents/ unaidspublication/2014/UNAIDS_Gap_report_en.pdf.

3. Ciesla JA, Roberts JE (2001) Meta-analysis of the relationship between HIV infection and risk for depressive disorders. American Journal of Psychiatry 158: 725-730.

4. Leserman J (2008) Role of depression, stress and trauma in HIV disease progression. Psychosom Med 70: 539-545.

5. Rueda S, Mitra S, Chen S, Gogolishvili D, Globerman J, et al. (2016) Examining the associations between HIV-related stigma and health outcomes in people living with HIVIAIDS: A series of meta-analyses. BMJ Open 6: e011453.

6. Ulasi Cl, Preko PO, Baidoo JA, Bayard B, Ehiri JE, et al. (2009) HIVIAIDSrelated stigma in Kumasi, Ghana. Health \& Place 15: 255-262.
7. Yi S, Chhoun P, Suong S, Thin K, Brody C, et al. (2015) AIDS-related stigma and mental disorders among people living with HIV: A cross-sectional study in Cambodia. PloS one 10: e0121461.

8. Gray LR, Brew BJ, Churchill MJ (2016) Strategies to target HIV-1 in the centra nervous system. Current Opinion in HIV and AIDS 11: 371-375.

9. Clifford DB (2017) HIV-associated neurocognitive disorder. Current Opinion in Infectious Diseases 30: 117-122.

10. Gibbie T, Mijch A, Ellen S, Hoy J, Hutchison C, et al. (2006) Depression and neurocognitive performance in individuals with HIVIAIDS: 2-year follow-up. HIV Medicine 7: 112-121.

11. WHO (2016) Prevent HIV, test and treat all-WHO support for country impact. Progress Report 2: 1.

12. Monforte AdA, Testa L, Adorni F, Chiesa E, Bini T, et al. (1998) Clinical outcome and predictive factors of failure of highly active antiretroviral therapy in antiretroviral-experienced patients in advanced stages of HIV-1 infection. Aids 12: $1631-1637$.

13. Teeraananchai S, Kerr S, Amin J, Ruxrungtham K, Law M (2017) Life expectancy of HIV-positive people after starting combination antiretroviral therapy: A meta-analysis. HIV Medicine 18: 256-266.

14. Mzingwane ML, Tiemessen CT (2017) Mechanisms of HIV persistence in HIV reservoirs. Rev Med Virol p: 27.

15. Reynolds NR, Testa MA, Marc LG, Chesney MA, Neidig JL, et al. (2004) Factors influencing medication adherence beliefs and self-efficacy in persons naive to antiretroviral therapy: A multicenter, cross-sectional study. AIDS and Behavior 8: 141-150

16. Pattanapanyasat K, Thakar MR (2005) CD4+ T cell count as a tool to monitor HIV progression and anti-retroviral therapy. Indian J Med Res 121: 539-549.

17. Asante KO (2012) Social support and the psychological wellbeing of people living with HIVIAIDS in Ghana. Afr J Psychiatry 15: 340-345.

18. Radzniwan R, Alyani M, Aida J, Khairani O, Jaafar NRN, et al. (2016) Psychological status and its clinical determinants among people living with HIV/AIDS (PLWHA) in Northern Peninsular Malaysia. HIV \& AIDS Review 15: 141-146.

19. Kaharuza FM, Bunnell R, Moss S, Purcell DW, Bikaako-Kajura W, et al. (2006) Depression and CD4 cell count among persons with HIV infection in Uganda. AIDS and Behavior 10: 105-111.

20. Ickovics JR, Hamburger ME, Vlahov D, Schoenbaum EE, Schuman P, et al. (2001) Mortality, CD4 cell count decline and depressive symptoms among HIV-seropositive women: Longitudinal analysis from the HIV Epidemiology Research Study. JAMA 285: 1466-1474.

21. Fincham D, Smit J, Carey P, Stein D, Seedat S (2008) The relationship between behavioural inhibition, anxiety disorders, depression and CD4 counts in HIVpositive adults: A cross-sectional controlled study. AIDS Care 20: 1279-1283.

22. Leserman J, Jackson ED, Petitto JM, Golden RN, Silva SG, et al. (1999) Progression to AIDS: The effects of stress, depressive symptoms and social support. Psychosomatic Medicine 61: 397-406.

23. Gonzalez JS, Batchelder AW, Psaros C, Safren SA (1999) Depression and HIV/ AIDS treatment nonadherence: A review and meta-analysis. J Acquir Immune Defic Syndr p: 58.

24. Boarts JM, Sledjeski EM, Bogart LM, Delahanty DL (2006) The differential impact of PTSD and depression on HIV disease markers and adherence to HAART in people living with HIV. AIDS and Behavior 10: 253-261. 